\title{
THE REVISED EU GSP+ \\ - NEW RULES TO PROMOTE SUSTAINABLE DEVELOPMENT
}

\author{
Magdalena Słok-Wódkowska ${ }^{\star}$
}

\section{Introduction}

The Generalized System of Preferences has been used for decades to promote international trade in developing countries. It was designed by the United Nations Conference on Trade and Development (UNCTAD) to assist developing countries to increase their export levels to developed countries. Although some doubts have arisen regarding the effectiveness of the GDP schemes, no developed states has decided to withdraw from the system.

The system introduced by the EU is the most complicated. It consists, in fact, of three separate systems, of which the most challenging and complicated is GSP+ - the special incentive for sustainable and good governance. The scheme, which has been operative in its current form since 2009, was reformed in 2012 and the revised GSP+ has been in force since 1.1.2014. It is therefore a good occasion to discuss the new scheme and offer some thoughts of evaluation.

* PhD. Institute of Public International Law, Faculty of Law and Administration, University of Warsaw. 
The first part of this article offers a general overview of the various GSP schemes in order to present the EU GSP as part of a broader picture. Furthermore, the history and general outline of the EU GSP are described before discussing the recent reforms of the system. The final two parts of the article contain remarks on the legality of the GSP+ from the perspective of WTO law and its effectiveness as a tool for attaining certain EU goals.

\section{Generalized System of Preferences as a Tool of Development through Trade}

The Generalized System of Preferences (GSP) is one of UNCTAD's flagship programs. When it was created in 1968 its aim was to accelerate the development and economic growth of developing countries by increasing their export and industrialization levels. ${ }^{1}$ As a tool to achieve this goal, tariff preferences were to be given unilaterally by developed countries to developing ones.

The GSP was adopted as a resolution during the second UNCTAD, although the idea of tariff preferences was presented in 1964 during the first conference. ${ }^{2}$ The system was supposed to be based, according to the resolution adopting the generalized system of preferences, on the assumption that developing countries would benefit from '...the generalized, non-reciprocal, non-discriminatory system of preferences'. However, from the very beginning it was abundantly clear that the system was not non-discriminatory and that it clearly, at least from a formal point of view, discriminated against countries other than 'developing' countries. ${ }^{3}$ It also violated the most-favoured nation clause - a pillar of the General Agreement on Tariffs and Trade (GATT) and some other integrating organizations. Despite such doubts, after the GATT parties

1 To read more about the beginning of GSP, see: A. Yusuf, Legal Aspects of Trade Preferences for Developing States, Martinus Nijhoff Publishers, The Hague 1982, pp. 81-83.

2 UNCTAD, http://unctad.org/en/Pages/DITC/GSP/About-GSP.aspx [last accessed on 16.8.2012].

3 J.H. Jackson, The World Trading System, Law and Policy of International Economic Relations, 2nd ed., MIT Press, Cambridge MA 1997, p. 322. 
adopted a waiver to tariff preferences for developing countries in 1971, the GSP became a popular policy tool used by developed countries in their relations with developing countries. Despite some attempts to create a single system of preferences, common for all developed states interested in granting preferences, each state has its own GSP with various governing rules.

Over forty years after the GSP resolution was adopted by the UNCTAD, only 10 states and the European Union have ratified the GSP schemes. ${ }^{4}$ Two of these (Belarus and the Russian Federation), despite claiming to possess GSP schemes, have not adopted rules governing the granting of preferences via UNCTAD. Furthermore, Belarus itself is a beneficiary of the GSP. Conversely, the Turkish system is not fully independent. Since Turkey is part of a customs union with the EU, its system should be identical to that of the EU GSP. ${ }^{5}$

Although every state (and the EU) has its own set of rules governing the granting of preferences, three general rules remain similar between the various systems. Firstly, states define a list of goods falling within the scope of a lower tariff rate. Secondly, they define a list of states eligible for preferential tariffs, the so-called 'beneficiary list'. Usually, states which obtain higher income for three consecutive years are withdrawn from this list, which applied in the past towards newly industrialized states. Thirdly, every system is based on strictly defined rules of origin which is, in fact, a crucial factor for granting preferences. In this respect significant differences exist between the various GSP schemes: each state has its own method for determining those rules. ${ }^{6}$ Some states have introduced

4 According to the UNCTAD website (http://unctad.org/en/Pages/DITC/GSP/AboutGSP.aspx [last accessed on 7.3.2014]) there are 13 national GSP schemes, but Estonia and Bulgaria (which are listed there) are currently EU Member States and do not have their own external trade policy.

5 Generalized System of Preferences: Handbook of the Scheme of Turkey, http://unctad. org/en/docs/itcdtsbmisc74_en.pdf, [last accessed on 7.3.2014]. This information has not been updated since 2007, when the scheme exactly mirrored the EU scheme.

6 Australia has only two requirements: the final manufacturing process must have been carried out in the country claiming preference and at least half of the total factory or works costs of the goods must consist of the value of labour and/or materials of one or more developing countries (albeit irrespective of which), Generalized System of Preferences: Handbook of the Scheme of Australia, http://unctad.org/en/Docs/ itcdtsbmisc56_en.pdf, [last accessed on 7.3.2014]; Canada requires import directly from 
limits on the quantities of goods that can be imported on preferential conditions. ${ }^{7}$ Most states give special preferences to the least developed countries (LDC), predominantly by granting them zero rates. ${ }^{8}$ South Korea targeted its GSP scheme exclusively to the least developed countries. ${ }^{9}$

As time has progressed, the GSP has been treated by developed states as unconditional development aid for selected poorer countries. Recently, the European Union and, in part, the United States have tried to achieve other goals via their GSP schemes. They grant preferences not merely because a given developing country is poorer and needs some additional incentives to develop but also because the given country shares certain important values with the EU or the US. They grant so-called conditional preferences in order to pursue certain political goals exceeding beyond mere economic aid. Such an attitude has been strongly criticized as a tool of protectionism, given the increased costs it entails in relation to fulfilling the requirements of the scheme. ${ }^{10}$

Those two schemes of the conditional GSP are based on completely different requirements. ${ }^{11}$ The EU grants additional preferences in the GSP+

a state that is covered by GSP, Generalized System of Preferences: Handbook of the Scheme of Canada, http://unctad.org/en/PublicationsLibrary/itcdtsbmisc66rev1_en.pdf, [last accessed on 7.3.2010]; Switzerland grants preferences to goods made of products from developing countries and Switzerland, the European Union and Norway, Generalized System of Preferences: Handbook of the Scheme of Switzerland, http://unctad.org/en/ PublicationsLibrary/itcdtsbm28rev3_en.pdf [last accessed on 7.3.2014].

7 Japan limits imported agriculture and fisheries goods, Generalized System of Preferences: Handbook of the Scheme of Japan GSP, http://unctad.org/en/Docs/ itcdtsbmisc42rev4_en.pdf [last accessed on 7.3.2014].

8 E.g. Japan, Australia, Canada and New Zealand, Generalized System of Preferences: Handbook of the Scheme of New Zealand, http://www.unctad.org/en/docs/itcdtsbmisc48_ en.pdf [last accessed on 16.8.2012].

9 Handbook on the preferential tariff scheme of the Republic of Korea in favour of least developed countries, http://unctad.org/en/PublicationsLibrary/itcdtsbmisc75_en.pdf [last accessed on 7.3.2014].

10 Critical opinions for example expressed: G. Shaffer, Y. Apea, Institutional Choice in the Generalized System of Preferences Case: Who Decides the Conditions for Trade Preferences? The Law and Policies of Rights, 'Journal of World Trade' 2005, vol. 39, no 6, at pp. 997-1008 .

11 Detailed comparison: O. Chaundhary, The propriety of preferences: an evaluation of EC and US GSP schemes in the wake of EC-preferences, 'Asper Review of International Business and Trade Law' 2005, vol. 5, at pp. 159-194. 
scheme (details of which are discussed later in this article) while the US can simply exclude states from the system as a consequence of finding that such states violate workers' rights or intellectual property rights, or give rise to other statutory concerns. ${ }^{12}$

The US gives preferences to developing beneficiary countries as regards some eligible products enumerated in a list. Eligible commodities are only those imported directly from a beneficiary developing country. Although eligible countries - both BDC (beneficiary developing countries) and LDBDC (least developed BDC) - can export eligible articles to the US duty free, the list of those articles is broader in respect of LDBDC countries. This means that, in contrast to all other developed countries possessing GSP schemes, the US offers a zero tariff rate to all beneficiary countries (though only as regards certain enumerated goods) and provides additional preferences to LDC countries in the guise of an additional list of commodities covered by the GSP and not by additional tariffs reduction.

Obviously, the fact that a given country is on the list and that an article is eligible for the tariff reduction is not, by itself, a guarantee that it will be covered by the preferences. According to Section 2462 of the U.S. Code, Title 19 - Custom Duties, the President of the US shall not designate as eligible a country which, for example: violates US law governing intellectual property rights; which acts in a manner that can have significant adverse effect on US commerce; that has nationalized, expropriated or otherwise seized ownership from any US citizens; which has failed to take steps to afford internationally recognized workers' rights to workers in the country. The list of requirements is not precise and leaves a wide margin of discretion for the US president to decide whether any of the excluding conditions have been fulfilled. The system though is completely different from the very rigid GSP+ found in the European Union. ${ }^{13}$

12 See: US Generalized System of Preferences Guidebook, July 2013, http://www. ustr.gov/sites/default/files/GSP\%20Guidebook_Final_06262013.pdf, [last accessed on 7.3.2014].

13 More on the US GSP Scheme: G.M. Grossman, A. Sykes, A preference for development: the law and economics of GSP, 'World Trade Review' 2005, vol. 5, at p. 44. 


\section{Generalized System of Preferences of the European Union}

The European Community (EC) implemented its first GSP scheme in 1971, immediately after the decision of the GATT contracting parties to waive tariff preferences for developing countries. In 1995 the EC decided to introduce some elements of a conditional GSP, initially based on the same mechanism as the US GSP. It became possible to suspend preferences if a developing country failed to adhere to human rights and the basic principles of workers' rights.

The first complete scheme of the positive conditional GSP was introduced by Council Regulation (EC) No 2501/2001 of 10 December 2001 applying a scheme of generalised tariff preferences for the period from 1 July 2002 to 31 December 2004. ${ }^{14}$ In this regulation several conditional preferences were laid down. For example, Article 21 of regulation 2501/2001 introduced additional incentives for environmental protection - tariffs could be reduced on the importation of tropical wood from countries which obey the rules of international conventions concerning tropical timber or whose national legal systems contain other norms governing the sustainable usage of tropical timber. Other additional preferences were granted to developing countries for combating the production and trafficking of drugs and for introducing norms of the International Labour Organization concerning workers' rights.

The initial system of preferential GSP was completely modified in 2005 in a new EU GSP perspective for the years 2006-2015. In a Communication entitled 'Developing countries, international trade and sustainable' development: the function of the Community's generalised system of preferences (GSP) for the ten-year period from 2006 to $2015,{ }^{15}$ the European Commission stated that a priority of the EU tariffs preferences is, firstly, to provide aid for least developed countries (according to the United Nations criteria) and, secondly, to simplify the GSP scheme. Consequently, all countries which had received preferences on some other legal basis (e.g. international agreements between the EU

14 O.J. 31.12.2001, L 346, p. 1.

$15 \operatorname{COM}(2004) 461$ final. 
and its member states and third countries) now fall outside the scope of the GSP. The GSP programmes were restricted to only three: (1) a regular GSP accessible to all developing countries (except those which are entitled to receive preferences on some other basis); (2) the 'Everything but arms' programme dedicated to the least developed countries, which can obtain a zero tariff rate for every article exported to the EU countries, except for military articles; (3) the GSP+ programme, enabling a zero tariff rate to be obtained by those developing but not least developed countries that fulfil certain specified conditions.

Although the Commission admitted, in 2005, that the previous conditional GSP had proven to be inefficient (a very small number of developing countries benefitted from the programme), it decided not to resign from the promotion of sustainable development and corporate governance via additional preferences. As stated in the Communication, the Commission expected that such promotion should become more effective only thanks to the usage of pre-existing international instruments, such as multilateral conventions concerning human rights, environmental protection and workers' rights as well as internationally agreed mechanisms for supervising and implementing those conventions.

The reformed EU GSP scheme, including so called GSP+, entered into force on 1.7.2009 pursuant to Council Regulation (EC) No 732/2008 of 22.7.2008 applying a scheme of generalised tariff preferences for the period from 1.7.2009 to 31.12.2011 and amending Regulations (EC) No 552/97, No 1933/2006 and Commission Regulations (EC) No 964/2007 and No 1100/2006. ${ }^{16}$ According article 8 thereof, a special incentive can be granted for so-called 'vulnerable' countries which have ratified and effectively implemented all 27 conventions listed in Annex III to the regulation. Countries deemed to be vulnerable are those which do not have a diversified export base and lack competitiveness on the European market.

A state which has ratified all relevant conventions and is convinced of its effective implementation of those conventions is required to file an application with the Commission. This is only possible bi-annually. Subsequently, the process of verification commences. The granting of preferences depends exclusively upon the Commission's assessment of the

16 O.J. 6.8.2008, L 211, p. 1. 
implementation. However, the Commission may use internationally agreed instruments (mainly laid down in a given convention) to verify how the convention has been implemented in the country applying for additional preferences. The Commission should take into account any information provided by a relevant international organization. The Commission did not, in fact, investigate the genuine effectiveness of the implementation process itself. It also was unable to take into account the validity of any reservations to the conventions made by an applicant state. The criteria for granting preferences were, therefore, strongly formalized.

According to article 7 of Regulation 732/2008, the special incentive was understood as suspending all duties on products imported from countries included in the special incentive arrangement. Nevertheless, the tariffs reductions are limited only to those eligible goods listed in annex II of the Regulation. Effectively, this list is limited to sensitive goods. As regards non-sensitive goods, all tariffs are set at a zero rate pursuant to the general arrangement. In other words, the additional benefits which accrue to an applicant state which fulfils these quite serious requirements are relatively limited.

\section{Revised GSP scheme of the EU}

Traditionally, consecutive GSP schemes were designed to apply only for a three year period. That established in 2008 was designated to expire in 2011. The scheme was prolonged by the so called 'roll-over Regulation', ${ }^{17}$ but it was intended that it would be replaced by a new scheme in 2014 .

In May 2011 the European Commission presented a draft regulation intended to replace regulations $732 / 2008$ and 512/2011. The final text was agreed in June 2012 and accepted by the Council in October 2012. Currently, the GSP scheme is based on Regulation (EU) No 978/2012 of the European Parliament and the Council of 25 October 2012 applying a scheme of generalised tariff preferences and repealing Council Regulation

17 Regulation (EU) no 512/2011 of the European Parliament and the Council of 11.5.2011, amending Council Regulation (EC) no 732/2008 applying a scheme of generalised tariff preferences for the period from 1 January 2009 to 31 December 2011. 
(EC) No 732/2008. ${ }^{18}$ Unlike previous schemes, the newest scheme is designed to apply for ten years until 2023, except special arrangement governing LDCs which do not indicate an expiry date.

The Commission's original proposal explained that the primary aim of these reforms was to ensure the increased effectiveness of the system and its better adjustment to a changing world. ${ }^{19}$ Although only minor changes were made to the general scheme and the introduced EBA scheme, a difference exists in the list of eligible countries. According to the Commission, tariffs are currently set at a relatively low rate and since many developed and middle income countries acquire preferential access on the basis of regional trade agreements. Accordingly, the impact of reduced tariffs is limited and the poorest countries are forced to compete with middle income countries. Moreover, some middle income countries, even whilst lacking agreements with the EU, were classified as eligible under previous GSP schemes. All of these countries were excluded under the current scheme, as 'graduated economies'. Moreover, all countries that have preferences granted on some other legal basis (mainly regional trade agreements) are ineligible to be granted GSP. Consequently, the list of eligible countries was slightly narrowed.

The list of countries eligible for preferences was not only limited but also reorganized. There are separate lists of countries eligible for preferences, LDC countries and an empty list of countries entitled to grant GSP+ preferences. All of the appendices comprising lists can be amended by the Commission by way of delegated legislation. This makes the list more flexible and easier to adjust. The European Commission was also given the right to adopt delegated acts regulating the list of eligible products and certain other frequently changing factors.

Beside amendments aimed at adjusting the scheme to ensure compatibility with the Lisbon Treaty of the EU (with its reformed system of legal acts and competences) and minor amendments to the country list, the majority of amendments introduced by the new scheme concerned GSP+. Firstly, the 'vulnerability' criteria were slightly changed and the share of GSP imports as a percentage of the EU's GSP imports was increased from $1 \%$ to $2 \%$. According to the Commission, there are still

18 O.J. 31.10.2012, L 303, p. 1.

19 See explanatory memorandum to the $\operatorname{COM}(2011) 241$, p. 1. 
only 35 countries which meet the vulnerability criteria under the current legal framework. ${ }^{20}$ Only such countries are eligible to apply for GSP+.

The list of conventions ${ }^{21}$ was supplemented by the addition of the United Nations Framework Convention on Climate Change (UNFCCC), whereas the International Convention on the Suppression and Punishment of the Crime of Apartheid was removed from the list. This latter change does not seem to be significant. The crime of apartheid is probably not a serious threat nowadays and the same goal - the prohibition of racial discrimination - can be attained through other international instruments contained in the lists, such as the convention on the Elimination of All Forms of Racial Discrimination. Conversely, adding UNFCCC to the list is a visual sign of the importance of climate change in the EU policy. The impact of the change is nevertheless very limited, since the list has always included the Kyoto Protocol to the UNFCCC.

A more effective and transparent mechanism for monitoring and evaluating the implementation of relevant international conventions has also been introduced. According to Article 9 of the Regulation, it is no longer sufficient to ratify the conventions. A provision concerning reservation must also be added. This should be perceived as representing an added value. Some developing states could, despite having ratified a convention concerning (for example) the rights of women or children, subsequently add reservations which targeted and undermined essential elements of the particular convention. ${ }^{22}$ Conversely, however, a requirement concerning reservation is not particularly strong and may only be questioned if the EU or a majority of state parties object to a given reservation or if 'a process explicitly set out for that purpose under the convention has so determined'.

20 Information Notice for countries which may request to be granted the special incentive arrangement for sustainable development and good governance under Regulation (EU) no 978/2012 of 31.10.2012, http://trade.ec.europa.eu/doclib/docs/2012/ november/tradoc_150043.pdf [last accessed on 14.3.2014].

21 Annex VIII to the Regulation.

22 E.g. reservations to the Convention on the Elimination of All Forms of Discrimination against Women (CEDAW), which contains reservations made by the majority of Arabic states concerning Sharia law, which seems to give rise to doubts from the perspective of the Convention's aim. 
According to the Commission, ${ }^{23}$ the new regulation will also increase the effectiveness of the requirements for beneficiary countries to effectively implement the conventions. Article 15 of the regulation enables the Commission to temporarily withdraw a country's beneficiary status if it fails to effectively implement the conventions in practice. It is worth mentioning that a list of requirements concerning implementation of the conventions has also been widened. It is stressed that a beneficiary country is obliged not merely to ratify the conventions but also to accept related reporting and monitoring requirements.

Finally, a significant change concerns the time for applying for additional preferences. Unlike in the case of previous schemes, there is no one fixed date for filing applications. A country which fulfils the relevant requirements may file for additional preferences at any time it is ready to do so. GSP+ may be granted immediately upon verification of the application by the Commission.

The current list of beneficiary states was published by the Commission on 30.12.2013 and consists of only ten countries: Armenia, Bolivia, Cape Verde, Costa Rica, Ecuador, Georgia, Mongolia, Paraguay, Pakistan and Peru. ${ }^{24}$ Applications were also filed by El Salvador, Guatemala and Panama. Each of these countries, with the exception of Pakistan, benefited from GSP+ under the previous legal framework. It is also noteworthy that, among the aforementioned states, Costa Rica, Peru, El Salvador, Guatemala and Panama have already signed trade agreements with the EU, while Georgia has initialled one prior to signature later in 2014. Accordingly, all of these states will benefit from the GSP+ only on a temporary basis.

The limited number of states which benefit from the very complicated and ambitious scheme for additional preferences raises questions concerning its effectiveness. Nonetheless, before analyzing the effectiveness of the system, its legality must first be discussed.

23 Ibid., p. 2.

24 http://trade.ec.europa.eu/doclib/press/index.cfm?id=1006 [last accessed on 13.3.2014]. 


\section{GSP+ Legality}

It must be said that, since it provides for non-mutual tariff preferences, the GSP is generally contrary to WTO law, namely the GATT's most favoured nation clause and the principle of non-discrimination. As noted above, the granting of unilateral preferences to developing countries in fact discriminates against every other country.

It was obvious from the very beginning that a problem would arise concerning the incompatibility between the UNCTAD proposal for granting preferences and Article I of the GATT, which states that:

[w]ith respect to customs duties and charges of any kind [...] any advantage, favour, privilege or immunity granted by any contracting party to any product originating in or destined for any other country shall be accorded immediately and unconditionally to the like product originating in or destined for the territories of all other contracting parties.

This conflict was resolved in 1971 by the adoption of a waiver ${ }^{25}$ applicable for ten years, which enabled developed countries to grant tariffs preferences within the framework of GSP schemes. ${ }^{26}$ In 1979 the GATT parties adopted a Decision on Differential and More Favourable Treatment, Reciprocity and Fuller Participation of Developing Countries, ${ }^{27}$ which is commonly known as the 'Enabling Clause'. This decision applies without time limits and has remained in force until today (since 1995 as a constituent part of the GATT 1994).

25 Waiver - Permission granted by WTO members allowing a WTO member not to comply with its normal commitments. Waivers have time limits and extensions must be justified, WTO glossary, www.wto.org.

26 To read more about waiver and the enabling clause, see: J.H. Jackson, W.J. Davey, A.O. Sykes, Legal Problems of International Relations, Casus, Materials and Text, WestGroup, St.Paul Minnesota, 1995, p. 1126; N. Santos, R. Farias, R. Cunha, Generalized System of Preferences in General Agreement on Tariffs and Trade/World Trade Organization: History and Current Issues, 'Journal of World Trade' 2005, vol. 39, no 4, at pp. 637-670.

27 Decision of 28.11.1979, L/4903. 
However, it must be highlighted that the enabling clause covered only traditional GSP, which was granted without any conditions. For this reason, conditional GSP schemes such as the GSP+ should be examined separately. A key element regarding the legality of the conditional GSP from a WTO perspective are the Panel and the Appellate Body reports issued in the case of European Communities - Conditions for Granting of Tariff Preferences to Developing Countries. In this case, India alleged that the EC's GSP scheme, including additional and conditional preferences, infringed the Enabling Clause. India claimed that the special arrangements for combating drug production and trafficking, for the protection of labour rights and for the environment, created undue difficulties for India's exports to the $\mathrm{EC}^{28}$ and was, accordingly, inconsistent with the requirements laid down in the Enabling Clause. Although reports had been issued on the basis of a concrete dispute, both the Panel and the Appellate Body generally referred in their reports to any conditions pursuant to which preferences could be granted by developed countries. Consequently, the reports (especially the report of the Appellate Body) can be used to assess the legality of the present GSP+.

The Panel's report had been strongly against tariffs preferences being granted to developing countries pursuant to the fulfilment of any condition. According to the Panel, the conditionality of preferences is contrary to the aim of the Enabling Clause, which was aimed at enabling the provision of unconditional help. The Panel stated that any differences in tariff rate between countries can only be explained by their different needs, as resulting from their various stages of development. In the Panel's view, the intention of the GATT contracting parties when they agreed on the Enabling Clause was to fulfil certain special development needs of poorer countries. There is no reasonable basis for distinguishing between development needs 'whether they are caused by drug production and trafficking, or by poverty, natural disasters, political turmoil, poor education, the spread of epidemics, the magnitude of the population, or by other problems, ${ }^{29}$ and therefore there should be no difference between

28 http://www.wto.org/english/tratop_e/dispu_e/cases_e/ds246_e.htm, [last accessed on 14.3.2014].

29 European Communities - Conditions for Granting of Tariff Preferences to Developing Countries, WT/DS246/R, Panel Report, 1.12.2003, para. 103. 
tariffs reduced in respect of developing states fighting drug production and trafficking and those simply attempting to overcome a development gap. Given the Panel's interpretation, any GSP scheme based on conditional preferences should be regarded as inconsistent with the Enabling Clause. It would also be unlawful to use the GSP as a tool with which to conduct any kind of political aims other than the simple provision of support for economic growth.

Nevertheless, doubts that could have arisen after the Panel's report were subsequently explained by the Appellate Body. Although the Appellate Body did not reverse the Panel's judgment, it disagreed with its reasoning. The Appellate Body, concurring with the EC's arguments, compared the Enabling Clause to Article XX of the GATT (the general exception). It underlined that, despite the fact that both Article XX and the Enabling Clause constitute exceptions to the most-favoured nation clause, in contrast to Article XX the Enabling Clause is a positive mechanism, supporting international trade and not creating additional restrictions. ${ }^{30}$ Moreover, the Appellate Body stated that the phrase 'to respond positively to development, financial and trade needs of developing countries', used in the paragraph 3(c) of the Decision of 1979, should be understood as concerning a broad variety of needs of developing countries, not merely economic needs. The response to such needs should be positive and should improve the development, financial or trade situation of a beneficiary country. Consequently, according to the Appellate Body, responses to the non-homogenous needs of developing countries must be non-discriminatory but need not necessarily be identical. ${ }^{31}$

By that reasoning, the Appellate Body changed the basic thesis of the Panel and its findings as regards EU conditional GSP, ${ }^{32}$ without changing the Panel's ultimate conclusion. ${ }^{33}$ In the Appellate Body's report it is,

30 European Communities - Conditions for Granting of Tariff Preferences to Developing Countries, Appellate Body Report, WT/DS246/AB/R, 7.4.2004, paras 96-99.

31 Ibid., paras 163-166.

32 Ibid., para. 174.

33 More comments of the jurisdiction: G. Duran, E. Morgera, WTO India-EC dispute: The future of Unilateral Trade Incentives Linked to Multilateral Environmental Agreements', 'Review of European Community and International Environmental Law' 2005, vol. 14, no 2, at pp. 173-179; M. Irish, GSP Tariffs and Conditionality: A comment on EC Preferences, 'Journal of World Trade' 2007, vol. 47, no 4, at pp. 683-698; M. McKenzie, 
in fact, possible to find criteria useful for assessing the legality of any conditional GSP scheme: ${ }^{34}$

(1) any special incentive should be aimed at ensuring a positive response to the special development, financial and trade needs of a developing country,

(2) the existence of such special needs must be assessed according to broadly agreed, objective criteria, set out in the WTO Agreement or in any other international instrument,

(3) the nature of such need should be such that it can be addressed by tariffs preferences,

(4) identical preferences are available to all developing countries covered by the GSP scheme, not only de iure but also de facto.

The current EU GSP+ should be assessed on the basis of the aforementioned criteria. Firstly, we should examine the aim of the special incentive. The whole of chapter III of the Regulation, together with recital 11 of the preamble to the Regulation, clearly states that the aim of the special incentive is to ensure sustainable development and good governance. Both aims are commonly recognized as important needs for every country in the world. Sustainable development is mentioned in the preamble to the WTO Agreement. Good governance is understood as standards of human rights, working conditions, combating drugs trafficking or fighting corruption and these are undoubtedly broadly agreed values and aims both within the WTO system within other international organizations, including the United Nations.

Conversely, certain authors ${ }^{35}$ claim that the development needs of various states can differ and, thus, the requirement to ratify a unified set of conventions fails to meet their individual special needs. As a result, the first criterion would not be met. According to Wardhaugh, additional preferences should be adjusted to suit the special needs of a given country. This author does not entirely concur with such a requirement. Recital 11 of

European Communities - Conditions for the Granting of Tariff Preferences to Developing Countries, 'Melbourne Journal of International Law' 2005, vol. 6, pp. 118-140; J. Stamberger, The Legality of Conditional Preferences to Developing Countries under the GATT Enabling Clause, 'Chicago Journal of International Law' 2003, vol. 4, no 2, at pp. 607-618.

34 Classification based on: G. Duran, E. Morgera, op. cit., p. 176.

35 See: B. Wardhaugh, GSP+ and Human Rights: Is the EU'S Approach the Right One?, 'Journal of International Economic Law' 2013, vol. 6, at p. 836. 
the Regulation strongly underlines the fact that a country's development needs can be understood as sustainable development needs. In such a context, the EU's insistence that a given country undertake efforts to address sustainable development through international conventions can be perceived as a minimum standard requirement.

Differentiating needs and requirements might also be perceived as discriminatory. Using internationally agreed standards helps to fulfil the fourth criterion. Identical preferences are in fact available to all developing countries covered by the GSP scheme, not only de iure but also de facto. Both economic (vulnerability) and legal (ratification of the conventions) are accessible without any differences to all developing countries which are not covered by more preferential instruments such as regional trade agreements (which are compatible with WTO law). Certain problems existed with the fact that filing for additional preferences was previously possible only until a fixed date, ${ }^{36}$ but this has been resolved under the revised scheme.

There rather represents a further problem with first criterion. If a country has ratified all of the necessary conventions, we may assume that it no longer has any problems in ensuring human rights, sustainable development and good governance. ${ }^{37}$ Although the GSP+ additional preferences is a reward for the efforts and costs borne by a given state for having ratified and implemented the conventions, this does not mean that it addresses any development needs. It leaves certain doubts remaining as regards the first criterion.

Simultaneously, using multilateral conventions with a high number of ratifications as a tool of assessment proves that the second criterion has been fulfilled. The GSP+ is available for every country covered by the general EU GSP insofar as it meets objective, economic criteria. The Commission uses international instruments to verify the implementation of the conventions, which may serve as proof that the instrument is nondiscriminatory.

A further problem exists as regards verifying whether sustainable development and good governance could be addressed through tariffs

36 See: L. Bartels, The WTO legality of the EU'S GSP+ arrangement, (10.8.2007), available at SSRN: http://ssrn.com/abstract=986525, [last accessed on 14.3.2014.], p. 11.

37 Ibid., p. 7. 
preferences. This, in fact, questions the effectiveness of the system as a tool for promoting those values and aims. If the system is ineffective, it should also be treated as inconsistent with the WTO Enabling Clause.

\section{GSP + effectiveness}

There are several questions concerning the effectiveness of the GSP+ scheme. First, there is a question concerning the real added value arising from the ratification and implementation of conventions. As table 1 below shows, the majority of conventions have been ratified by a huge number of countries. Taking into account that there are around 195 countries in the world, ${ }^{38}$ some conventions have been ratified by almost all of them, obviously including vulnerable countries. It must be said that the catalogue of chosen conventions reflects the most important conventions which enjoy the largest number of ratifications.

Table 1. Conventions that need to be ratified to get additional preferences in the GSP+ scheme

\begin{tabular}{|c|c|c|}
\hline No & TITLE OF THE CONVENTION & No of Parties \\
\hline \multicolumn{3}{|c|}{ HUMAN RIGHTS CONVENTIONS } \\
\hline 1. & International Covenant on Civil and Political Rights & 167 \\
\hline 2. & International Covenant on Economic, Social and Cultural Rights & 161 \\
\hline 3. & International Convention on the Elimination of All Forms of Racial Discrimination & 176 \\
\hline 4. & Convention on the Elimination of All Forms of Discrimination Against Women & 187 \\
\hline 5. & $\begin{array}{l}\text { Convention Against Torture and other Cruel, Inhuman or Degrading Treatment or } \\
\text { Punishment }\end{array}$ & 154 \\
\hline 6. & Convention on the Rights of the Child & 193 \\
\hline 7. & Convention on the Prevention and Punishment of the Crime of Genocide & 144 \\
\hline \multicolumn{3}{|c|}{ ILO CONVENTIONS } \\
\hline 8. & Convention concerning Minimum Age for Admission to Employment (No 138) & 166 \\
\hline
\end{tabular}

38 It is impossible to categorically state the number of countries, since some are controversial and are not universally recognized. 193 states are members of the United Nations. 


\begin{tabular}{|c|c|c|}
\hline No & TITLE OF THE CONVENTION & No of Parties \\
\hline 9. & $\begin{array}{l}\text { Convention concerning the Prohibition and Immediate Action for the Elimination of } \\
\text { the Worst Forms of Child Labour (No 182) }\end{array}$ & 178 \\
\hline 10. & Convention concerning the Abolition of Forced Labour (No 105) & 174 \\
\hline 11. & Convention concerning Forced or Compulsory Labour (No 29) & 177 \\
\hline 12. & $\begin{array}{l}\text { Convention concerning Equal Remuneration for Men and Women Workers for Work } \\
\text { of Equal Value (No 100) }\end{array}$ & 171 \\
\hline 13. & $\begin{array}{l}\text { Convention concerning Discrimination in Respect of Employment and Occupation } \\
\text { (No 111) }\end{array}$ & 172 \\
\hline 14. & $\begin{array}{l}\text { Convention concerning Freedom of Association and Protection of the Right to } \\
\text { Organise (No 87) }\end{array}$ & 152 \\
\hline 15. & $\begin{array}{l}\text { Convention concerning the Application of the Principles of the Right to Organise and } \\
\text { to Bargain Collectively (No 98) }\end{array}$ & 163 \\
\hline \multicolumn{3}{|c|}{ ENVIRONMENTAL CONVENTIONS } \\
\hline 16. & Montreal Protocol on Substances that Deplete the Ozone Layer & 197 \\
\hline 17. & $\begin{array}{l}\text { Basel Convention on the Control of Transboundary Movements of Hazardous Wastes } \\
\text { and Their Disposal }\end{array}$ & 181 \\
\hline 18. & Stockholm Convention on Persistent Organic Pollutants & 179 \\
\hline 19. & Convention on International Trade in Endangered Species of Wild Fauna and Flora & 180 \\
\hline 20. & Convention on Biological Diversity & 194 \\
\hline 21. & Cartagena Protocol on Biosafety & 167 \\
\hline 22. & United Nations Framework Convention on Climate Change & 196 \\
\hline 23. & Kyoto Protocol to the United Nations Framework Convention on Climate Change & 192 \\
\hline \multicolumn{3}{|c|}{ ANTIDRUGS CONVENTIONS } \\
\hline 24. & United Nations Single Convention on Narcotic Drugs (1961) & 153 \\
\hline 25. & United Nations Convention on Psychotropic Substances (1971) & 183 \\
\hline 26. & $\begin{array}{l}\text { United Nations Convention against Illicit Traffic in Narcotic Drugs and Psychotropic } \\
\text { Substances (1988) }\end{array}$ & 188 \\
\hline \multicolumn{3}{|c|}{ GOOD GOVERNANCE CONVENTION } \\
\hline 27. & United Nations Convention against Corruption (Mexico). & 170 \\
\hline
\end{tabular}

Source: Own study based on UN, http://treaties.un.org, [last accessed on March 2014]

At the same time an analysis of recent ratifications of those conventions shows, that countries does not seem to be especially eager to ratify them in order to obtain some additional preferences. Among 
countries specified in the Annex ${ }^{39}$ to the Regulation 732/2008 and Regulation 978/2012 since 2005 the highest number of conventions (10) from the list has been ratified by Samoa, Vanuatu and Lao, recently joined by Guinea-Bissau, but all four are least developed countries covered by the EBA scheme of preferences which is more preferable than the GSP+ scheme. Very recently also Maldives, the only country which is eligible to apply for the GSP+ reached the number of ten ratifications of the conventions from the list, mainly thanks to ratification of all 8 Fundamental Conventions of the International Labour Organization in January 2013..$^{40}$

Brunei signed or ratified 9 conventions from the list and Bahrain ratified 9 , but they are high income countries, which are not vulnerable even though they are beneficiary countries of a general GSP. Another few countries (Angola, Somalia and East Timor, Sao Tome and Principe) ratified between 9 to 7 conventions, but they are all LDC covered by EBA scheme.

Among eligible countries also Pakistan ratified 7 conventions between 2005 and 2012. It is though worth to notice, that it started to meet vulnerability criteria only recently under changed rules, while previously its share of the trade with the EU in its total external trade is too high. Pakistan was granted the GSP+ status under the revised scheme. A state that actually took an advantage of the GSP+ scheme is Cape Verde, which obtained the GSP+ in December 2011, as it graduated from the EBA and managed to ratify all necessary conventions on time. Cape Verde prolonged its GSP+ status in 2014.

Among 'vulnerable' countries also Iraq has relatively high number of recent ratifications, as from 2005 it ratified 8 of them. It is difficult to judge if its efforts to implement international instruments for good governance and sustainable development has the objective of obtaining the GSP+ additional preferences. Iraq, as well as Kazakhstan, which recently ratified 6 conventions but has too high share of the EU exports to meet vulnerability criteria, have both some other obligations towards the

39 Also South Sudan ratified recently 11 of the 27 conventions on the list, it is not on the list of eligible developing countries.

40 The Maldives joined the ILO in 2009, so this probably represents the reason for such an increase in the number of ratifications. 
EU resulting from bilateral agreements. On the other hand higher than average number of ratifications in recent years of those countries can also be explained by some political changes that occurred there.

A few other countries, such as Gabon or Palau, were seen as potential beneficiaries of the GSP+, but are currently not listed as vulnerable countries. Palau ratified three conventions and signed four others in 2011, but still remains to ratify 13 in order to obtain GSP+ status. Gabon still needs to ratify 5 conventions. Both of these countries are ACP countries, which means that other arrangements govern their relations with EU. An individual strategic plan may also offer an additional incentive to ratify international conventions - a special kind of agreement between the EU and an ACP country in order to gain accessed to funds from the European Development Fund. ${ }^{41}$ Such strategic plans usually include some form of obligation to implement international instruments concerning, for example, environmental protection or human rights. It also explains the high number of ratifications by countries eligible for EBA, such as Vanuatu. Conversely, the EU is not as major trading partner for Vanuatu or Palau.

Those conventions that have not been ratified by the majority of developing countries would probably be costly or difficult to implement, for cultural or political reasons. Among such conventions are the majority of those concerning working conditions (ILO conventions). Another group of conventions might be problematic to ratify because of a country's stance on anti-drugs politics. Most of the conventions from this group concern criminal law and require states to ruthlessly combat the production and trafficking of drugs. Surprisingly, environmental conventions seem to enjoy the highest number of ratifications by developing countries. This can be explained by the fact that they are based on the principle of common but differentiated responsibility for environmental protection and as a universal instrument are rather general in character (regional instruments seem to be more restrictive). Good examples of such conventions are the Kyoto Protocol or the Convention on Biological

41 The Country Strategy Paper \& National Indicative Programme (For the Period 2008-2013) has been signed by every ACP country eligible for EDF. 
Diversity. This also demonstrates that no significant change would be felt if the United Nations Framework Convention on Climate Change were added to the list of required conventions.

Aside from the choice of conventions and their implementation costs, other questions exist as regards the advantages that a developing country may acquire as a beneficiary of the GSP+ scheme. The least developed countries have no incentive to seek additional preferences, since they are already covered by the 'Everything but Arms' program. Other developing countries are required fulfil onerous conditions in order to qualify for preferences that are narrow in scope, due to the limited number of products falling within their scope. Even the authors of a report prepared for the European Parliament ${ }^{42}$ admitted that GSP+ is not an incentive to ratify conventions but, rather, a kind of bonus for those who are already committed to those goals. This causes one to return to the question above concerning GSP+ as a means of addressing special development needs.

It must also be noted that the economic benefits arising from lower tariffs are rather limited. States being lower and middle income economies compete on the European market not only with LDCs or other developing states covered by the general GSP arrangement. Numerous low and middle income (and developed) countries enjoy access to the EU market on preferential terms, on the basis of various international agreements. The EU has free trade agreements with certain ACP countries (Caribbean countries, Papua and New Guinea and some African states) or on the basis of special preferences for overseas countries and territories.

Moreover, diminished tariffs do not really lead to an increase in international trade and exports from GSP+ countries. ${ }^{43}$ Therefore it is probably not truly economically justified to ratify all conventions in order to obtain additional preferences under GSP+, especially since the eligibility criteria are subject to change every three years.

42 Reform of the Generalized System of Preferences, European Parliament, Directorate-General for External Policies of the Union, Policy Department Study, p. 5.

43 See: P. Folfas, M. Słok-Wódkowska, Export from developing countries to the EU Member States under GSP+ scheme, paper presented at the ETSG conference in Leuven, 2012. http://www.etsg.org/ETSG2012/Programme/Papers/475.pdf [last accessed on 15.3.2014]. 


\section{Conclusion}

The revised EU GSP scheme certainly does not constitute a revolution. The amendments are rather minor and the basic rules of the system remained unchanged. The amendments introduced by Regulation 978/2012 should, when compared to the previous scheme, be assessed positively. They eliminated doubts concerning accessibility of the scheme for all interested developing countries, by enabling a GSP+ application to be filed at any time. This removed the earlier legal uncertainty which existed, thanks to the ten-year period for which the scheme was designed. It also lessened the requirement to meet vulnerability criteria, which open the GSP+ to a broader range of states, even though they still remain very few in number. The most important amendment involved strengthening the possibility for a state to be temporarily withdrawn from the scheme if it had failed to effectively implement all of the relevant conventions.

Despite this positive assessment it should be though underlined that, given the narrow scope of amendments, the majority of the scheme's weak points remain. The amendments have done nothing to quell doubts concerning the legality of the scheme and, last but not least, the effectiveness of the scheme. The GSP + still offers additional preferences only for those who have ratified all of the conventions for other reasons. It is a reward, as opposed to an incentive, for sustainable development and good governance. 